INTERNATIONAL HIGHER EDUCATION NUMBER 65 FALL, 2011

Pages $19-20$

International Lessons for Africa's Higher Education and Economy

Pundy Pillay

Pundy Pillay is professor of economics and public finance at the Graduate School of Public and Development Management, University of the Witwatersrand, Johannesburg, South Africa. He has been head of the Policy Unit in the South African Presidency. E-mail: pillayp@mweb.co.za and pundy.pillay@wits.ac.za.

What possible lessons can policymakers draw from the higher education and economic development experience of Finland, South Korea, and North Carolina (US)? This article contends that African countries should focus on the following areas: economic and education planning; high-quality schooling; institutional differentiation; the role of the state; regional development; and cooperation and networks.

\title{
ECONOMiC AND EdUCATION PlanNing
}

All three systems illustrate the benefits of maintaining a close link between economic and education planning. Likewise, in Finland, policy decisions were taken to focus on the development of a knowledge economy. In South Korea, the government has been unashamedly interventionist in both sectors to promote overall social and economic development. North Carolina does not hold a formal state government-induced planning in either the education or economic sectors. 
However, a close working relationship exists between the education and economic bureaucracies in the state government, the private-business sector, and public higher education institutions - to achieve the education and training, as well as research and innovation objectives, necessary for economic and broader development.

\section{High-QUALITY SCHOOLING}

Both the Finnish and South Korean models show how crucial high-quality schooling is for the development of a high-quality higher education system. Unlike in Finland and South Korea, the quality of schooling (and of higher education) in North Carolina varies substantially across the state.

\section{INSTITUTIONAL DIFFERENTIATION}

A dual/binary higher education system can be effective in meeting national development goals and has been developed in varying degrees in the three systems. In Finland, the two higher education subsectors have fundamentally different roles. In South Korea, there is clear functional differentiation between colleges and universities. In North Carolina, the postsecondary sector-including universities and community colleges-is appropriately differentiated to cater to the differing needs of the population and the economy. However, with little differentiation within the university sector, almost all of them aspire to becoming "world-class" research institutions. 


\section{The State's Role}

The Finnish system demonstrates that the state through its role-inter alia, in funding-can ensure the development of a higher education system that is appropriate to the country's needs. In South Korea, the state has chosen to play a much more dominant role in the development of the schooling systemcompared to higher education, which is largely private. In North Carolina, the role of the state is that of a facilitator and a serious funding source. As a facilitator it has driven important partnerships with the private-business sector and higher education institutions.

\section{Regional DeVelopment}

In Finland, universities and polytechnics spread over the entire country in collaboration with one another and with local government and business to ensure greater equity in regional development. South Korea is now addressing regional development through such initiatives as the New University for Regional Innovation.

\section{COOPERATION AND NETWORKS}

The Finnish system is characterized by a high degree of consensus building and cooperation between stakeholders in the higher education system-including institutions, government, public-funding agencies, and the private sector. This has been a key factor in stimulating efficiency and effectiveness in the distribution of resources and the development of appropriate education and research outcomes. 
In Korea, the hand of government is clearly "visible" in all components of the education system, including oversight of the private sector. Historically, an important network has been the collaboration between the relevant government ministries, the public-research institutions, and the large private-sector companies (chaebols)—with respect to research and development. Increasingly today, universities, particularly the large public institutions, are becoming an important fourth component of this group, as they develop their research and development capacity.

The North Carolina case study shows how effective relationships can be developed between the higher education system, on the one hand, and government, the private-business sector, and civil society broadly, on the otherto promote economic, social, and environmental development. None of these affiliations have been legislated, but they have come about through a common commitment to the development of the state.

From the above, there are several important reasons why policymakers in sub-Saharan African countries should take note of the relevance of higher education for general development and economic development, specifically. The relationship between higher education and economic development is incontrovertible. Through its education and training as well as research functions, higher education can enable countries both to raise economic growth rates and increase participation in the knowledge-based economy. In the globalizing world, African countries do not need to base their economies solely on the production of primary commodities and manufactured goods, requiring skills provided by primary and secondary education. It is possible for developing/poor countries to focus likewise on the production of value-adding 
goods and services, requiring skills provided by the higher education system. The advantage of the latter strategy is that it can raise growth rates much more rapidly-enabling, inter alia, the government to expand the provision of economic and social services to people trapped in poverty.

China and India provide the best current examples of how developing countries have abandoned traditional patterns of economic development that characterized the growth paths of today's industrialized countries. To enable countries to develop a component of the knowledge economy within their borders requires the development of a productive higher education system. Obviously, this practice is limited by resource constraints and intersectoral competition for resources (e.g., schooling, health).

\section{CONCLUSION}

The case for African policymakers to undertake higher education seriously is a strong one from a development perspective. In this regard, consideration must be given to the following factors: (1) improving access to and quality in schooling; (2) linking education and, specifically, higher education to economic development policies; (3) ensuring clear institutional differentiation to enable optimal utilization of limited resources and more efficient attainment of development goals; (4) committing to the development of an equitable higher education system in terms of gender, socioeconomic status, and region. 